\title{
Research Paper: My Flower Has Only Four Thorns
}

\author{
Ana Maria Viegas Firmino
}

1. Professor, Department of Geography and Regional Planning, Faculty of Social Sciences and Humanities, New University of Lisbon, Lisbon, Portugal.

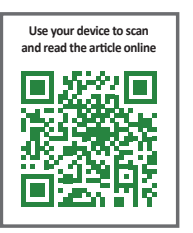

Citation: Viegas Firmino, A. M. (2017). My Flower Has Only Four Thorns. Journal of Sustainable Rural Development, 1(1), 83-88. https://doi.org/10.18869/nrip.jsrd.1.1.81

: https://doi.org/10.18869/nrip.jsrd.1.1.81

\section{Article info:}

Received: 23 Nov. 2016

Accepted: 10 Mar. 2017

\section{Keywords:}

Flowers, The vulnerability of plants, Permaculture design system, Symbol, Non-violent ideology

\begin{abstract}
A B STRACT
"My flower has only four thorns" expresses the vulnerability of plants confronted with a rate of destruction never experienced before, in spite of the valuable functions that they perform and the commercial value that they represent. In a short synthesis, the current article aimed at depicting an array of benefits and uses that flowers offer us, materially and emotionally, and introduce some movements that elect flowers as their symbol of a non-violent ideology.
\end{abstract}

\section{Introduction}

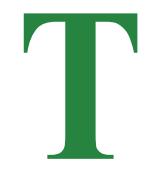

he book by Saint-Exupéry "The Little Prince" gives the title to this article about flowers from a geographic perspective. The author created the figure of a little prince who reports to a geographer what exists in the distant planet where he used to live. In his planet he had a flower, but the geographer did not seem interested in it, because flowers are ephemeral. As the little prince did not know what ephemeral meant, the geographer explained that it is something threatened to vanish in the short run. The little prince was deceived. The flowers are "the best of all", as he said, and in spite of ephemeral they fill up human imagery and are essential to human lives.

Indeed, life depends on plants, as directly or indirectly they provide humankind with oxygen, fuel, medicines, food, nutrients, clothes, and building materials. As Lipp and Colleagues point out, since pre-history, human beings used plants for their material value, but also acknowledged them for religious, esthetical, poetic, and moral significances (Lipp, 1997: 8). In the Middle-Ages the herb gardens in the cloisters were known as God's pharmacies and the virtues of plants are emphasized in different works, such as those of Pausch and Böhm (2007: 13) who praised these gardens not only for the supply of raw materials, but also for their flowery and scented splendor, that does so much good to the soul. Heilmeyer (2004) wrote that: "Flowers play a vital role as vehicles of expression. As declarations of love or as a gesture of thanks, as a means of conveying condolences or congratulations, flowers are often the most eloquent and direct means of communication."

In February 1890, van Gogh shared with his sister Wilhelmina the following feeling: "My pictures are after all

* Corresponding Author:

Ana Maria Viegas Firmino, PhD

Address: Commission on the Sustainability of Rural Systems, International Geographical Union, Beijing, China.

Tel: +351 (21) 7908300

E-mail:am.firmino@fcsh.unl.pt 
almost a cry of anguish, although in the rustic sunflower they may symbolize gratitude” (Duncan, 1986: 145).

Flowers, as part of the flora, contribute to the balance in the ecosystems, which is absolutely necessary for the survival of humankind, and are used in plenty in sustainable modes of production such as organic farming. Food and medicine were used from the old times to prepare teas and medicaments for humans and animals.

Poisonous, sweet, bitter, magical, and hallucinogenic; each one has a specific function! Even as a plaything (fuchsias or sweet-peas). Their essences exhale perfume, their colors seduce for their charm. They are present in the good and bad moments and carry the symbols of the past events ("The Hippy Movement" in the 60's or the Carnation Revolution in Portugal in 1974).

The use of flowers is still common in some occasions in particular societies such as the Indian, Haitian, or Timoree; namely in parties, weddings, or ceremonies to welcome visitors, the participants being adorned with necklaces made of flowers as a friendly gesture.

In a different social context, and although it is less and less common, in Western societies the bridegroom used to wear a flower in the lapel of the coat and the bride is supposed to throw the bouquet among the single girls attending the wedding, as the tradition says that the one who will catch it will find her love.

Flowers may also be a symbol of royalty as the heraldic fleur-de-lis in France. In art, they have been a constant source of inspiration, in movements such as Art Nouveau, which emerged as a reaction against the academic art of the 19th century, or as a leitmotiv in different painting schools, van Gogh (1853-1890) being one of the most known for his sunflowers.

Sunflowers were selected by Steiner (1861-1925) to explain the influence of the planets on the plants. During the set of conferences in Koberwitz, Breslau, and Germany (in the 20's of the last century), he launched the fundamentals of biodynamic farming, based on anthroposophy. According to this author, the seed irradiates the cosmic forces, which cross upwards the leaf and the flower. Thus, when a plant is pulled out, in the roots lays the cosmic element, while in the flower the earth element prevails; permeating the cosmic force only in the most delicate tint of the color (Steiner, 2001: 53-54). The yellow and white in the sunflower, for instance, was determined by the influence of Jupiter, while the red color in the rose shows the presence of Mars. His studies state the influence of the cosmic energies and planets on plants and animals, on which the Calendar of Maria Thun, used mostly in biodynamic farming, is based. This calendar informs about the best days to plough, seed, harvest, etc., according to the classification of root, flower, leaf, and fruit as Maria Thun explains in her book "Pratiquer la Bio-Dynamie au Jardin" (2004).

After many years of evolution, the diminishing of biodiversity at a very fast rate is a threat that should be reversed. And although new species are created, namely through bio engineering (GMO's and High Yield Varieties), the imbalances caused to the ecosystems can endanger the survival of humankind. Not that the earth will die, since if Sir James Lovelock (1989) is right, man disappears, but Gaia survives, meaning that the ecosystems will have the capacity to regenerate. As "The Little Prince" would say: "Thus, my flower is threatened to vanish in the short term? ... My flower is ephemeral ... and it only has 4 thorns to protect itself from the whole world. And I left it unattended!" (Saint-Exupéry, 1993: 82).

\section{The World on a Bunting Clover Map}

In 1582 Heinrich Bünting (1545-1606) published the map of "The World on a Bunting Clover" in the "Itinerarium Sacrae Scripturae." This map is outstanding for its originality and is used here to illustrate the epopee of the plants during the period of the discoveries, which was particularly important to broaden the knowledge about the flora, acclimatization, and distribution of plants in the world (Figure 1)

According to Correia (2006: 354) the "Portuguese played an extremely significant role in the exchange of plants between the continents, as a result of their effects on their economies, in the development of agriculture, and in the change of dietary habits." The importance of the exchange of plants between the continents during the Portuguese discoveries in the 16th and 17th centuries is also emphasized by Ferrão (1994: 5) as "It has undoubtedly had some of the most marked and long-lasting scientific, technical, economic, and social repercussions."

Several authors contributed to the study of plants and their medicinal use, such as Garcia de Orta (1500-1568) a Portuguese physician and naturalist, who arrived in Goa in 1534, benefiting from the knowledge that he got from the Ayurvedic practitioners, as one can read in his book "Colóquio dos Simples".

1.http://www.booktryst.com/2012/04/three-strange-andbeautiful-16th.html 


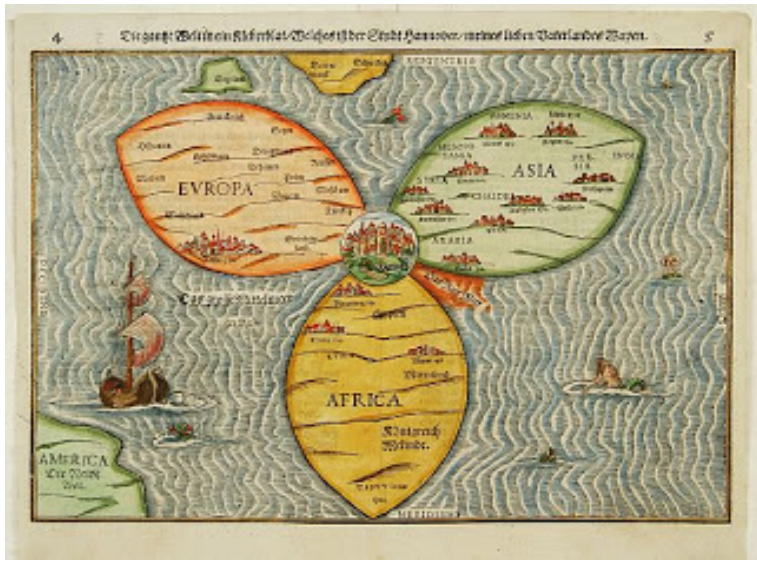

Figure 1. The world on a bunting clover

JSRD

Scientists such as Alexander von Humboldt (17691859) transcended the mere identification of the species, characterized in the first descriptions by explorers, to establish a relationship between the occurrence of some species and the climate, altitude, geographic latitude, and soil. Zimmerer wrote that: "Another source of the expanding interest is Humboldt's renowned vision of nature and landscapes through a perspective of the inseparability of humans and the environment. As a result, Humboldt's oeuvre regained relevance in the context of today's heightened concerns over environmental change, human-induced crisis, and conservation" (Zimmerer, 2006: 456).

The destruction of the Amazon rainforest, one of the world's greatest natural resources, described as the "Lungs of the Planet", as it produces about $20 \%$ of earth's oxygen, is one more example of the Tragedy of the Commons, as Garrett Hardin, in 1968, called it; i.e. the depletion of a shared resource by individuals. In 1993 Gary McCuen examined the controversies surrounding the destruction of the tropical rainforest in his book "Ecocide and Genocide in the Vanishing Forest: The Rainforest and Native People." The vanishing Amazonia rainforest, whose canopy scientists believe can contain half of the world's species, lost 3.6 million hectares annually in the past decade.

More than $20 \%$ of the Amazon rainforest is destroyed forever. Cattle ranches, mining operations, logging, and subsistence agriculture claim the land. Some forests are sacrificed to supply the charcoal for industrial plants. In the past 5 decades, fire and logging destroyed the bigger half of the rainforests. More than 200000 acres of forests are burnt every day worldwide, or better to say more than 150 acres per minute. It is estimated that some 130 species of plants, animals, and insects are lost every day.
Based on the current destruction rate, it is estimated that in less than 40 years' time, the rainforests are destroyed.

For centuries, the inhabitants of the Amazon rainforest apply a variety of the plants as cures and potions for their health and survival. Scientists discovered that many of the plants are used as the sources of new drugs for AIDS, cancer, diabetes, arthritis, and Alzheimer's. Quinine, muscle relaxants, steroids, and cancer drugs have been already discovered. A total of 121 prescription drugs have plant-derived sources. Only $1 \%$ of tropical plants are tested, and almost $25 \%$ of all drugs are derived from rainforest ingredients.

Five hundred and forty years after its publication, the world on a bunting clover leaf map could symbolize the global village, taking into consideration the paradigms valid today and the dialectics between man and the environment, expressed in Humboldt's work, reappear animated by a new life's breath consubstantiated in the concept of sustainable development.

\section{Where Have All the Flowers Gone?}

The 60's were a period of history marked by the war in Vietnam. Groups of young people rebelled against the values prevalent in society at that time and started the Hippies movement.

It seems a long time now as Pete Seeger wrote the song: "Where have all the flowers gone", in 1961. It aimed at denouncing the violence of war and the deaths that it caused: "Where have all the graveyards gone? Covered with flowers every one; when will we ever learn?"

Some years later Scott Mackenzie popularized the song San Francisco (be sure to wear some flowers in your hair). This song was written in 1967 by John Phillips, and talked about the flower people, as the people in motion. The hippie movement launched the "Flower Power" as a slogan and a symbol of a non-violent ideology opposing the dominant trend in society. The hippies used flowers in the hair, in necklaces, and even their cars and clothes were decorated with this element.

They shocked the most conservative minds with their exuberance and style of life, namely for their sexual behavior. Make love not war is still a very popular slogan!

In the 80's many had become yuppies and the hippie movement lost relevance. Curiously, today a new peace movement tries to change the values prevalent in society and to find the path towards sustainability based on 


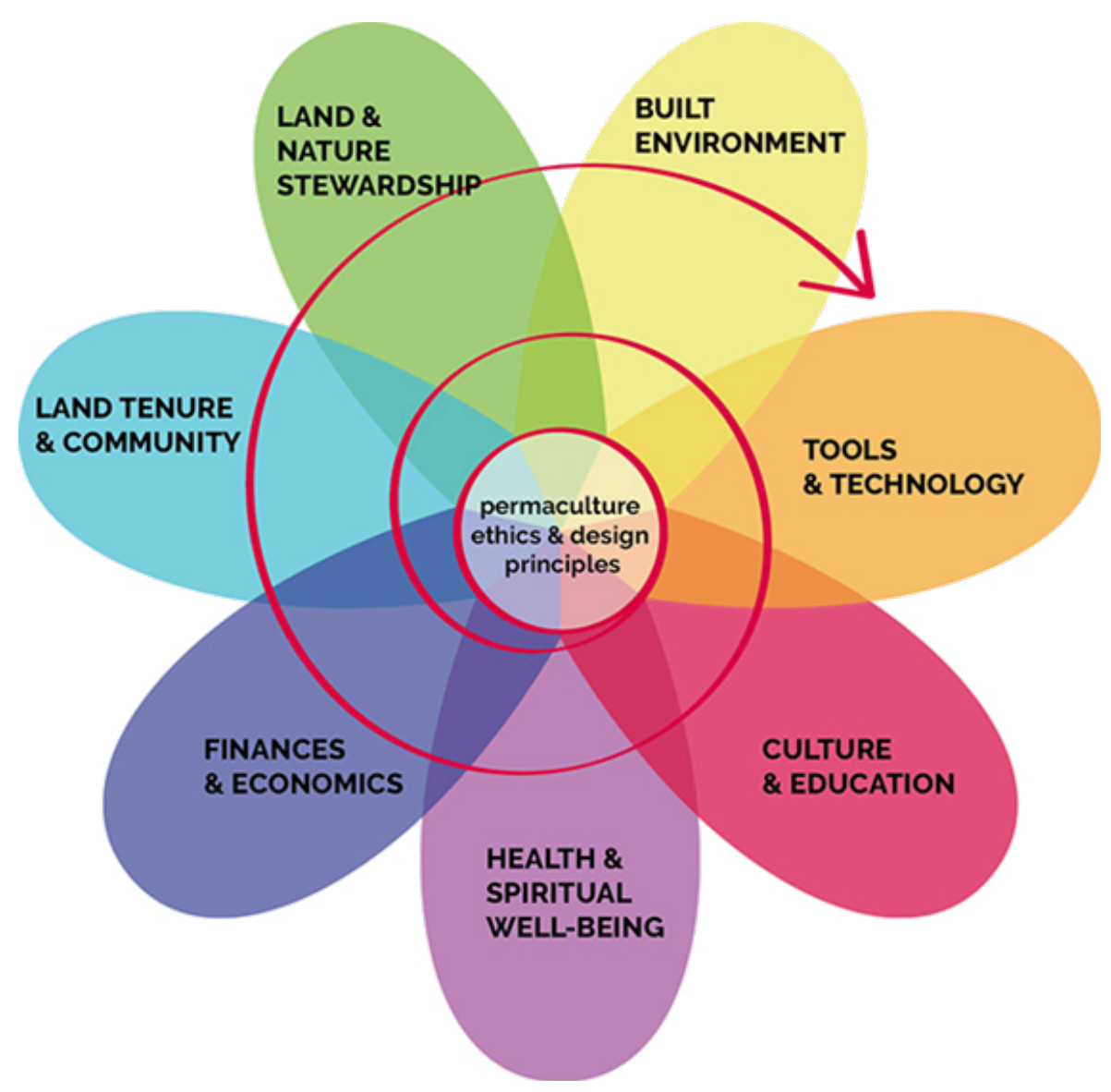

Figure 2. Permaculture design system

resilience. They base their existence on the permaculture concept, created by Bill Mollison and David Holmgren, in the 70's, which evolved into a life philosophy with a holistic approach based on seven tools: Land and nature stewardship; 2) Built environment, tools, and technology; 3) Culture and education; 4) Health and spiritual well-being; 5) Finances and eco nomics; and 6) Land tenure and community governance (Figure 2).

They are less visible in the media than the hippies, but they have been working steadily, looking for new concepts that they apply, such as the transition town concept, created by Rob Hopkins aimed at preparing society for an economy without oil. Some of them are organized in the Global Ecovillages Network (GEN) ${ }^{2}$ and several groups are engaged in different kinds of projects.

Some of these groups are newly founded communities, groups of neighbors in a city quarter, or members of universities. The Faculty of Social and Human Sciences (FCSH) of the New University of Lisbon, just started a working group called "FCSH in transition" composed of masters students attending the subject geography of

2. GEN - Global Ecovillage Network, www.gen.ecovillage.org/ globalization, who intend to organize actions to promote a better environment inside the faculty, reduce energy consumption, improve the nutritional quality of the food served in the refectory, and interact with society to promote new values based on trust and solidarity. A site called "Unihortas" is also planned to give visibility to the work being developed by the Portuguese universities with urban allotments. In the case of the FCSH, the urban allotment (located in the Botanic Garden of Museum of Dress in Lumiar) ${ }^{3}$ is maintained by the common effort of students, staff, and docents of the faculty together with homeless volunteers in collaboration with International Association of Doctors (AMI) ${ }^{4}$ and mainly produces herbs donated to that association.

One of the most known communities where the principles of transition and permaculture are applied is Findhorn ${ }^{5}$, in Scotland. The community started in the 60 's with three adults and three children who lived in very precarious conditions, since they had no job.

\footnotetext{
3. www.museudotraje.imc-ip.pt

4. www.ami.org.pt

5. www.findhorn.org/
} 


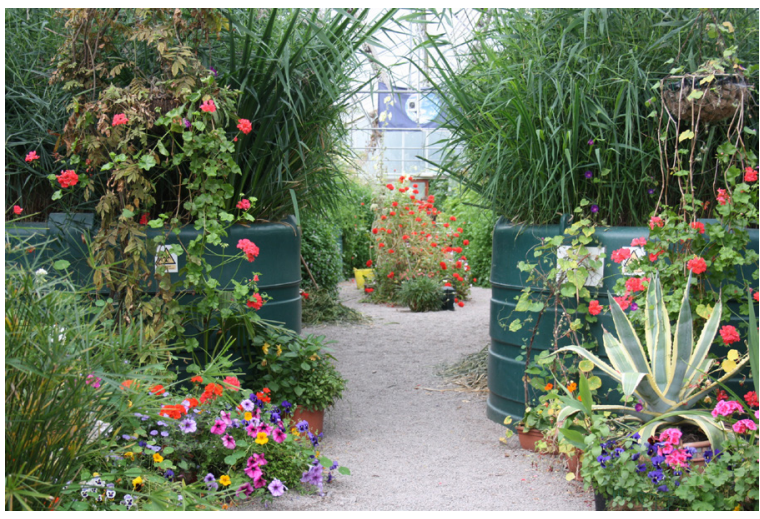

C JSRD

Figure 3. The "Living Machine" in findhorn, scotland (Author's photo)

Today they have about 200 individuals and they are expanding the built area.

The relevance of this community to this paper is the fact that they use plants to treat their sewage. The "Living Machine" is a greenhouse composed of several containers with plants that have the capacity to depurate the water, such as Phragmitis, and whose principle is similar to the one used in the biologic swimming pools ${ }^{6}$. Its proper work has some rules, namely the strict interdiction to use non-biodegradable products at home or throw plastic bags and other rubbish into the drain pipes (Figure 3). One more function performed by the plants to help man to keep the essential resources!

\section{How a Flower Can Change the World}

Nature has supplied mankind with water, food, fibers, and shelter which have permitted the survival of the human species up to now. In the beginning, the humanoids only had to collect the available plants (recollection period). Little by little, they started selecting them, and it is estimated that about 10 million years ago they practiced agriculture. Throughout these millions of years, many species disappeared and others were created by selection and crossbreeding or due to hazards.

From a purely agronomic point of view, the flowers are a must to feed the bees that carry on the fructification through pollination. Their colors and odors attract the insects and, thus, they are used in organic farming to control plagues. An example is the nasturtium, that attracts aphids (an insect that sucks the juice of plants) and thus protects orchards, such as citrus trees. In consociation, they protect and improve the taste of other plants, as it is the case with savory that is beneficial for the green

6. www.biopiscinas.pt

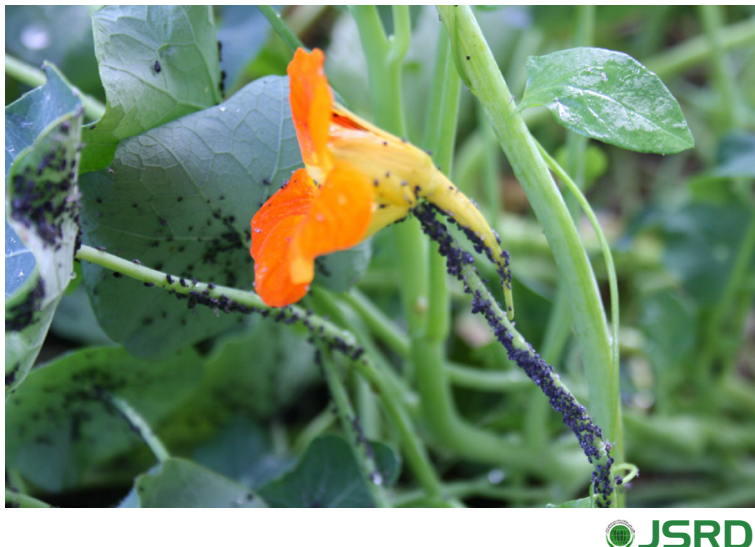

Figure 4. Nasturtium covered with aphids. (Author's photo)

beans. For some reason, the German word for savory Bohnenkraut - means "Green Beans Herb” (Figure 4).

In a useful book called "Tips From the Old Gardeners" Duncan Crosbie (2004: 8) explains that "Many plants classified as herbs contain natural chemicals that either encourage growth in other plants or protect them against pests and diseases. For example, cabbages thrive when they are planted around with sage, thyme, or rosemary; borage thrives strawberries; pot marigolds protect many surrounding plants by secretion of an insect repellent; parsley encourages bees and also protects asparagus, beans, carrots, etc.".

Flowers prevail human life directly or indirectly, physically or emotionally. They give the blue color to the jeans (indigo) and in the past they were used as a support to write (papyrus). Whether eaten (Physallis, Nasturtium, Borage, Nettle, Rose hips preserve) or drunk (elder flower elixir, for instance), they may simply improve the flavor of other ingredients (as savory) or be used as a medicine for man (Bach flowers remedies), plants or animals (biodynamic preparations - Horsetail, Nettles), and

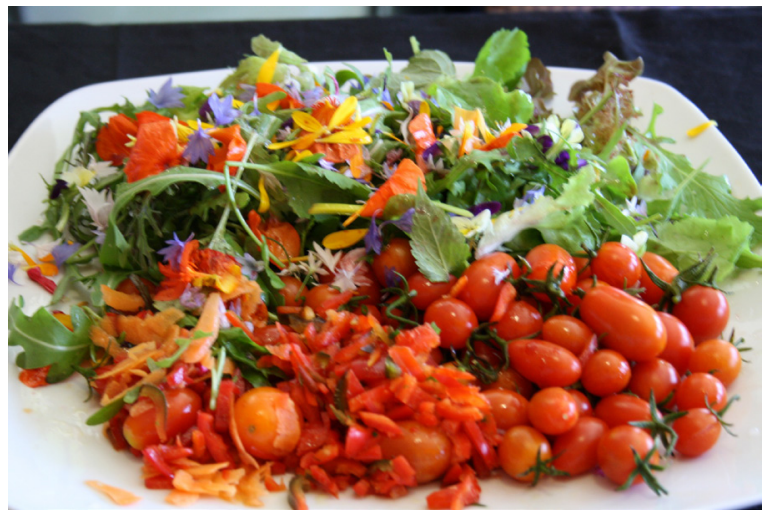

๑ JSRD

Figure 5. Gourmet salad prepared with edible flowers (borage, nasturtium, etc.) (Author's photo) 
to induce quietness (orange flower elixir) or relaxation (a bath of Rose petals or a massage with rosemary) as nowadays fashionable in spas.

Flowers are no doubt an attraction for tourists as so many examples in Portugal attest: Tray Festivities, in Tomar, religious celebrations such as Senhor de Santo Cristo at the Azores, or the Flower Fest at Madeira Islands and in Campo Maior. A more sophisticated attraction is the plant-themed amusement park Terra Botani$\mathrm{ca}^{7}$, in Anjou, located in the Loire Valley, also known as the "Garden of France". It explores the world of plants; offering the visitor plenty of information about the history of the plants, how they live, their natural habitats, horticulture, and landscaping throughout the ages, in an amazing way. They can also contribute to an interesting and rewarding business when used in gourmet dishes, served in expensive hotels or in tastings at the farm, as Figure 5 illustrates at Ervas Finas de Trás os Montes ${ }^{8}$, Vila Real, Portugal.

The flowers are also the comfort for many people, some of whom talk to them as if they could answer: ' $O$ Tiger-lily', said Alice, addressing herself to one that was waving gracefully about in the wind, 'I wish you could talk!'. 'We can talk' said the Tiger-lily: 'When there's anybody worth talking to' (Carroll, 1871).

Just like "a seed hidden in the heart of an apple is an orchard invisible" (Welsh proverb), a flower is the expression of the divine among people, something that means much more than one can see; as Saint-Exupéry wrote: "One sees clearly only with the heart. What is essential is invisible to the eye"!

\section{Acknowledgements}

This research did not receive any specific grant from funding agencies in the public, commercial, or not-forprofit sectors.

\section{Conflict of Interest}

The authors declared no conflict of interests.

\section{References}

Carroll, L. (1871). Through the looking-glass, and what Alice found there. New York: Macmillan Publishers.

Correia, L. A. (2006). Goa - Through the mists of history, from 10000 $B C-A D$ 1958. A select compilation on Goa's genesis. Goa: Maureen Publishers Pvt. Ltd.

Crosbie, D. (2004). Tips from the old gardeners, Oxford: Past Times Oxford

Duncan, D. D. (1986). Sunflowers for Van Gogh, New York: Rizzoli International Publications.

Ferrão, J. E. M. (1994). The adventure of plants and the Portuguese discoveries, Lisboa: The Institute of Tropical Scientific Research.

The Tragedy of the Commons. (1968). Science, 162(3859), $1243-$ 1248. doi: $10.1126 /$ science.162.3859.1243.

Heilmeyer, M. (2004). The language of flowers - Symbols and myths. Munich: Prestel Verlag.

Hopkins, R. (2008). Transition handbook - from oil dependency to local resilience. Totnes: Green Books Ltd.

Lipp, F. J. O. (1997). [Plant symbolism (Portuguese)]. Evergreen: Taschen $\mathrm{GmbH}$.

Lovelock, J. (1989). The ages of Gaia: A biography of our living earth. New York: W. W. Norton \& Company.

McCuen, G. E. (1993). Ecocide and genocide in the vanishing rain forest: The rainforests and native people (Ideas in Conflict Series). Mississippi: Gem Publications.

Orta, G. D. (1963). Colloquies on the simples $\mathcal{E}$ drugs of India. London: Henry Sotheran and Co.

Pausch, J., Böhm, G. (2007). [Health from the monastery; Old knowledge for body and soul (German)]. Erftstadt: Verlag Kettler.

Saint-Exupéry, A. (1993). [The little prince (French)]. San Diego: Harcourt Brace \& Company.

Steiner, R. (2001). [Bio-dynamic agriculture (Galician)]. São Paulo Livraria e Editora Antroposofica.

Thun, M. (2004). [Practicing bio-dynamics in the garden (French)]. Paris: Mouvement de l'Agriculture Bio-Dynamique.

Zimmerer, K. (2006). Humboldt and the history of environmental thought. New York: The American Geographical Society.

7. http://www.uk.terrabotanica.fr

8. http://www.ervasfinas.com 